RESEARCH ARTICLE

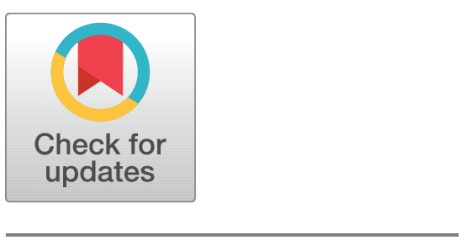

open access

Received: 06.08.2021

Accepted: 24.09.2021

Published: 25.01 .2021

Citation: Tupas FP, Banas LB (2021) Traditional Science learning in local recipes: A cross-disciplinary exposition. Indian Journal of Science and Technology 14(3): 197-207. https://doi.org/ 10.17485/IJST/v14i3.1332

* Corresponding author.

fernantupas@yahoo.com

Funding: None

Competing Interests: None

Copyright: @ 2021 Tupas \& Banas. This is an open access article distributed under the terms of the Creative Commons Attribution License, which permits unrestricted use, distribution, and reproduction in any medium, provided the original author and source are credited.

Published By Indian Society for Education and Environment (iSee)

ISSN

Print: 0974-6846

Electronic: 0974-5645

\section{Traditional Science learning in local recipes: A cross-disciplinary exposition}

\author{
Fernan Peniero Tupas ${ }^{1,2 *}$, Louiege B Banas ${ }^{3}$ \\ 1 Faculty, Department of Biology, Northern Iloilo Polytechnic State College, Estancia, Iloilo, \\ Philippines \\ 2 International Research Fellow, Japan Society for the Promotion of Science, Tokyo, Japan, \\ and Laboratory of Biotechnology and Bioengineering, Hokkaido University of Education, \\ Hakodate, Hokkaido, Japan \\ 3 Faculty, Hospitality Management Department, Northern Iloilo Polytechnic State College, \\ Ajuy, Iloilo, Philippines
}

\section{Abstract}

Purpose: The main objective of this research is to science concepts in local dishes and delicacies in 34 barangays in the Municipality of Ajuy, Iloilo, Philippines. Furthermore, to value its contribution to LGU and academe. Methods: This qualitative research specifically used ethnoscience through interviews, focus group discussion (FGD), and observation. But because of the pandemic, automated micro-targeting using Facebook (FB) was also used. All the responses of the informants were coded, analyzed, triangulated, and themed. Findings/application: Out of 34 barangays in the Municipality of Ajuy, 6 have local dishes, and 11 for local delicacies were recorded. However, most of these foods were not local from Ajuy but were adapted from neighboring places and islands. All the identified food, "barikutsa" (sugar and coconut milk candy) for delicacy, and "Patotin filled with Valenciana" for dish stood out the most due to no preservatives and processed ingredients. The local dishes and delicacies reflect the unique Philippine traditions-the abundance of local resources from land and sea. Informants identified nine science concepts: cooking techniques, traditional tools, taste, health benefits, local resources, preservation, fermentation, safety, and environmental friendly packaging. These local dishes and delicacies can be critical to the academe and local government units (LGU) such as livelihood programs, curriculum, OTOP, and cultural identity. As a result, the study suggested to different stakeholders in the municipality to work together to enhance the local cuisines. Also, it introduced "Patotin filled with Valenciana" and "barikutsa" in any municipal activities and encouraged educators to integrate into the curriculum. Ajuy's best and unique cookeries must be enhanced and preserved to boost tourism, and finally, improved way of living.

Keywords: Dishes and delicacies; local resources; science concepts; municipality of Ajuy 


\section{Introduction}

The breaking news about the coronavirus in January 2020 pushed the researchers to continue this study. The lockdown of many places in the country caused chaos to the Filipino people. The majority of the people in the country are not ready because most of them are receiving a daily basis salary - No work, No pay. But teaching them livelihood programs such as making delicacies and cooking local dishes can help them survive in this pandemic. They can sell these products to neighbors and friends that can help them earn income. Thus, the foodservice industry is the fashions in this time of the pandemic. Records showed in 2016, the revenues were about 535.9 billion pesos and exponentially increased to 616 billion pesos in 2019 with almost 3,126 establishments ${ }^{(1)}$. These exposed that Filipinos are food lovers.

Filipinos, by nature, love a variety of food from classic as well as sweet native delicacies. The entire archipelago offers meticulously prepared local dishes that symbolize the sweetness and closeness of every Filipinos ${ }^{(2)}$. Furthermore, Filipinos are famous around the world for eating three to five times a day; this proved that Pinoy has an obsession with food. Filipino food is thrilling, astonishing, but one unique feature of each Filipino cuisine is full of delightful flavors ${ }^{(3)}$. For instance, Ajuy, different local restaurants, and food stands are everywhere. Aside from that, local vendors are also selling delicacies inside the markets or in the streets.

There are around 120 different ethnic groups and mainstream communities in the Philippines. Thus, each group such as Tagalog, Ilocano, Pampango, Pangasinan, and Visayan lowlanders showcasing methods of food preparation. But the invasion of Chinese introduced "pansit" or noodles; "lumpia" or vegetables rolled in edible wrappers; "siopao" or steamed, filled buns and "siomai" or dumplings. While the Spaniards presented the production of food for an elite, non-food-producing class, and a portion of food for which many ingredients were not locally available. Then, cuisines were influenced by French, Italian, Middle Eastern, Japanese, Thai, Vietnamese introduced all over the archipelagoes ${ }^{(4)}$. Malay food heritage showed there are similarities and differences from north to south influenced by myriad cultures. The Malay food from past and present, results of practices and characteristics can contribute to the literature on food culture ${ }^{(5)}$.

Thus, every island has something exceptional to offer to visitors, both local and international. Tourists were always having positive comments with a beautiful smile upon returning home because of the mouth-watering local dishes served during their stay. For instance, in Panay, the freshest ingredients from seafood and local farm products, the Department of Tourism (DOT) organized a culinary and travel festival. The DOT facilitated this event because Iloilo has various food to offer that many foreigners were appreciated ${ }^{(6,7)}$. But none of the northern Iloilo cuisines were introduced. Thus, the researchers were motivated to engage in this study.

Also, this study is significant to the program of the government One Town One Product (OTOP) because this will identify one specific product that best represents each municipality. The findings of the research will encourage the local government units (LGUs) in the northern part of Iloilo to create dishes or delicacies using local resources. OTOP was a program of former President Gloria Macapagal-Arroyo to support local entrepreneurship as well as a job. The regional executives all over the country are given the task of pinpointing local products for competitive advantages. OTOP's primary goal is to support micro, small, and medium enterprise (MSMEs) by creating products from indigenous materials ${ }^{(8)}$. Today, in activities like town fiesta, festivals, province day, you can see various dishes and delicacies as your own products of the LGU. In 2012 Seman sang Iloilo, Estancia presented their dried fish products, but Balasan didn't participate ${ }^{(9)}$.

Specifically, the Department of Biology of Northern Iloilo Polytechnic State College (NIPSC) Main Campus, Estancia, Iloilo, Philippines, and Hospitality Management Department of NIPSC, Ajuy Campus, Ajuy, Iloilo, Philippines commissioned this study. NIPSC, as the only tertiary institution in the $5^{\text {th }}$ District of Iloilo ${ }^{(10)}$, aims to quality education for the people in the north. Research and extension are the two pillars of the college. Thus, the researchers planned to identify unique recipes in the municipality and enhance local resources to make Ajuy's delicacies. Then, in the future, with the help of LGU, NIPSC, and other stakeholders, conduct an extension program to provide a livelihood to the residents for social development.

One survey revealed that local delicacies found in the municipality of Laguna contributed a significant impact on the tourism industry. Some of these local delicacies are Buko pie, "Kesong puti," Mernels and Cassava Cake, Cassava chips, Uraro, Bibingka, and Ube. These native foods are considered to improve the culinary tour of the province ${ }^{(11)}$. Also, foreign tourists visit places to experience and taste new food because socialization is always associated with food served during vacation ${ }^{(12)}$. Furthermore, rice delicacy is a food heritage in Naic, Cavite, as an agricultural area that produced vast rice. But currently, the production of this farmed product was exponentially declining; the manufacturing of rice delicacy was also affected. The authenticity of the claim of rice delicacy as the food heritage of Naic has a significant effect. The local government unit (LGU) must take a move to restore the application by restoring the production of various rice products in the locality ${ }^{(13)}$.

The Municipality of Ajuy, blessed with bountiful resources both from water and land, every barangays has its unique dishes. Many of the recipes are not locally from Ajuy, but residents embraced and enhanced them with resources found in the areas. Thus, this study aims to identify the science concepts in local dishes and delicacies in 34 barangays of the Municipality of Ajuy, 
Iloilo, Philippines. Furthermore, to values its contribution to LGU and academe.

\subsection{Anthropological and Ethno-cultural Perspective}

Philippine gastronomies are knotted to culture and tradition. The more than 7,100 island in the Philippines serves as food haven to fishers, farmers and other locals. The abundance of resources allowed locals to prepare food most simply. The geographical location of the islands allowed neighboring countries to migrate and introduced their own culture and practices, specifically staple food, sauces and dips, signature dishes, and dining etiquette ${ }^{(14)}$.

Filipino cuisines are a mixture of Asian and European ingredients, like the famous Pork Menudo; some recipes are tomato sauce and soy sauce, and another blend with cheese and bay leaf with soy sauce. Additionally, in Southeast Asia, like the Philippines, the common ingredients are chilies, coconuts, shrimp paste, lemongrass, fish sauce, or "Patis" introduced by Chinese traders ${ }^{(15)}$. Thus, a variety of foods are found in the archipelagoes.

The article about "Origins Of Self" showed human society and each human in the community played by humans themselves. Hence, individuals' journey from childhood through adulthood is based on socialization and language ${ }^{(16)}$ - just like in the local cuisines that bind family and friends. Similar dishes and delicacies are found within the entire archipelago but with a twist and fusion of local resources commonly found in the areas. Thus, a study of local food always has a relationship with anthropology.

For instance, the beer, the flavor is good with nutritional values that affect the mind, medicine, and religion. Alcohol can help to relieve pains; hence, beer is safer than contaminated water. The production of beer started with discovering the usefulness of domestic products. Also, beers play a crucial role in all human interactions ${ }^{(17)}$.

The fondness and practices of our ancestors for food are always tricky to unveil. The discovery of different ancient cooking tools revealed the aspect of being human, and also uncovered the techniques from raw to a meal ${ }^{(18)}$.

Furthermore, the "lomi" in Batangas City, Philippines, has a significant effect on the locals because it provides income. It dramatically impacts the sociocultural context because it improves the local community relationship to religion and culture ${ }^{(19)}$.

"Balut" as one of the famous street food in the Philippines, is a duck egg. Duck is preferred because it has a strong shell and shell membrane. The perfect balut comprises embryo, yolk, rock, and soup and is incubated for around 16 to 18 days. Balut is part of the Philippine culture and provides livelihood programs for many Filipino around the country ${ }^{(20)}$.

The conservation of traditional rice varieties farming in the Province of Sarangani exposed cultural preservation and community solidarity. Still, the economic and socio-political conflict converted tribal communities, resulting in food insecurity. Remote areas are still practicing traditional farming, but human intervention like illegal logging, mining, and charcoal causes environmental degradation. But to Save the province, biological diversities coupled with indigenous and scientific knowledge are highly recommended ${ }^{(21)}$.

\subsection{Food Science and Technology}

Food-related choices have an important impact on health and food preparation methods linked to diet and health benefits but still not fully understood. The majority of the people are satisfied with food preparation. They are aspired to cook frequently utilizing raw ingredients because of social desirability. Home food preparation is elaborate, with varied practices, experiences, and perceptions. These concepts were learned from acquaintances ${ }^{(22)}$. Hence, learning about local foods is also discovering ideas on food science and technology. Regardless of old or new cuisines, food science and technology is always an integral part.

Like the bread and bakery, serves as a complement to dishes, food experts, and leading chefs innovate their crafts to have new offerings to valued clientele ${ }^{(23)}$. Today, technology is the trend in the food industry - this ensures quality and affordability. Furthermore, the machines used drives down the cost to keep food fresh, increase production, and eliminate safety issues ${ }^{(24)}$. Accordingly, consumers are essential to improving the product itself and industrial processing. The innovations of processing technologies and packaging are critical factors to attract more clients ${ }^{(25)}$.

\subsection{What is Science Concepts}

Teaching science concepts both in basic and tertiary education is a big task. But with all the resources available in the locality, just like teacher-led read aloud in first and second graders to introduce science concepts. The study revealed students able to create a mental representation of essential ideas ${ }^{(26)}$. The study led UChicago to expose students to scientific skills and knowledge to perform better. A brain scan, also showed learners in college Physics experienced hands-on strategies and methodology excellently in the exams ${ }^{(27)}$.

Science as a subject has many concepts, from teaching resources to facilities and equipment to biodiversity as well as people behind it. All those ideas are science itself, but in reality, science has many facets, such as: 
1. Science is both a body of knowledge and a process;

2. Science is exciting;

3. Science is useful;

4. Science is ongoing;

5. And science is a global human endeavor ${ }^{(28)}$

Thus, science is basically about scientifically discovering new ideas and principles. Science concepts defined as topics from specific to more complex, broken down to more convenient and workable for teachers and students ${ }^{(29)}$. Understanding local cuisine in Ajuy, the science behind it will give useful insights and knowledge.

\subsection{Ethnoscience}

Ethnoscience is about learning Science interconnected human anthropology and culture ${ }^{(30)}$. Ethnoscience Instruction (EI) allows students to find out knowledge between personal and societal. Traditional science learners exposed to ethnoscience instructions increase interest in learning the subject. The study showed rural school students had better performance than urban schools. Also, lowly educated parents performed better than highly educated parents ${ }^{(31)}$. Furthermore, the study about critical thinking ability using EI revealed students performed better than the control ${ }^{(32)}$. Moreover, Science education should always reflect society and culture despite the rapid development of technologies in recent years. But science programs today failed to include culture in the current curriculum for end-users ${ }^{(33)}$.

For instance, in agriculture, the impacts of global warming due to climate changes agreed with experts and policymakers to adapt traditional methods to ensure future food security. The strategies of using modern science contradict evidence that old-style knowledge of indigenous and local communities in agricultural techniques can help to cope with climate change ${ }^{(34)}$. Thus, in understanding local dishes and delicacies, culture and tradition play a significant role.

The study utilizing the ethnoscience approach and module theme acknowledged by the National Education Standard Agency (BNSP) of Indonesia is commendable. The results of the study showed improvement in students' learning outcomes and entrepreneurial skills and knowledge ${ }^{(35)}$.

\section{Methods}

\subsection{Research Design}

This qualitative research focused on ethnoscience that used the concept of "What of Cultural knowledge," and "Why of cultural behavior." In this study, the researchers identified science concepts in local delicacies and dishes in the town of Ajuy; thus, employing ethnoscience was targeted.

In detail, methods such as interviews, observations, and focused-group discussion (FGD) were facilitated in the study. The study started in November 2019 and ended in March 2020.

Furthermore, another method used is automated microtargeting. Social media such as Facebook (FB) is utilized to collect more data on specific local dishes and delicacies found in every barangay in the municipality. Also, the pandemic causes a significant effect on data collection; thus, FB plays a vital role in finishing the study on time.

\subsection{Epistemology of the Study}

This study is anchored on the Anthropology of Food because it focused on documenting the different local dishes and delicacies found in northern Iloilo, Philippines. Currently, there are lots of food experts and practitioners who captured their interest to study in detail about local foods in various locations. Since food is utterly essential to human existence; thus, the Anthropology of food is about analysis and exploring food and culture. Furthermore, this is a connection between eating habits and the social life perspective of the local community ${ }^{(36)}$. The study utilizing seven subsections to examine classic food ethnographies revealed the following themes; commodities and substance, food and social change, food security, eating and ritual, eating and identities, and instructional materials. But out of 7 subtopics, 3 were costly and intensive anthropological work; food security, eating practices and consumption, and identities ${ }^{(37)}$.

Thus, functionalism was the theory utilized in this research. Functionalism is motivated to understand the local culture from the standpoint of the native. Hence, functionalists stressed that anthropologists should seek to know how different parts of contemporary cultures work for the well-being of the individual and society. Not on how this phenomenon evolve. Society is interconnected; subsequently, any changes occur; another part will be affected as well ${ }^{(38)}$. 


\subsection{Study Area}

Figure 1 shows the map of northern Iloilo, Philippines, showing the location of the Municipality of Ajuy.

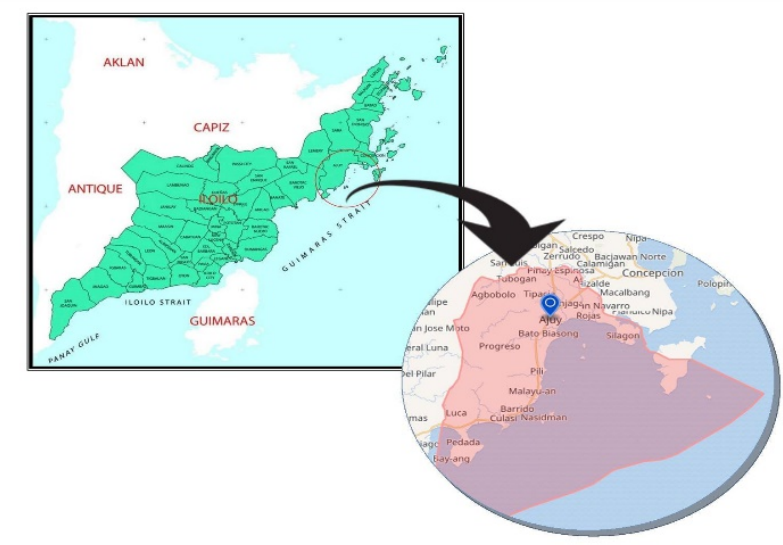

Fig 1. Map of Northern Iloilo, Philippines, showing Municipality of Ajuy.

The town is famous for fishing and agriculture, with a total of 19,346 hectares of land area is situated in the northern part of Iloilo. From Iloilo City, it takes two hours drive for around 91.9 kilometers away from the capital of the province ${ }^{(39)}$. As of 2015 , there are approximately 52,268 residing in 34 barangays in this $2^{\text {nd }}$ class municipality ${ }^{(40)}$.

\subsection{Data Collection}

Figure 2 shows the preliminary survey of the study and validation of collected data.

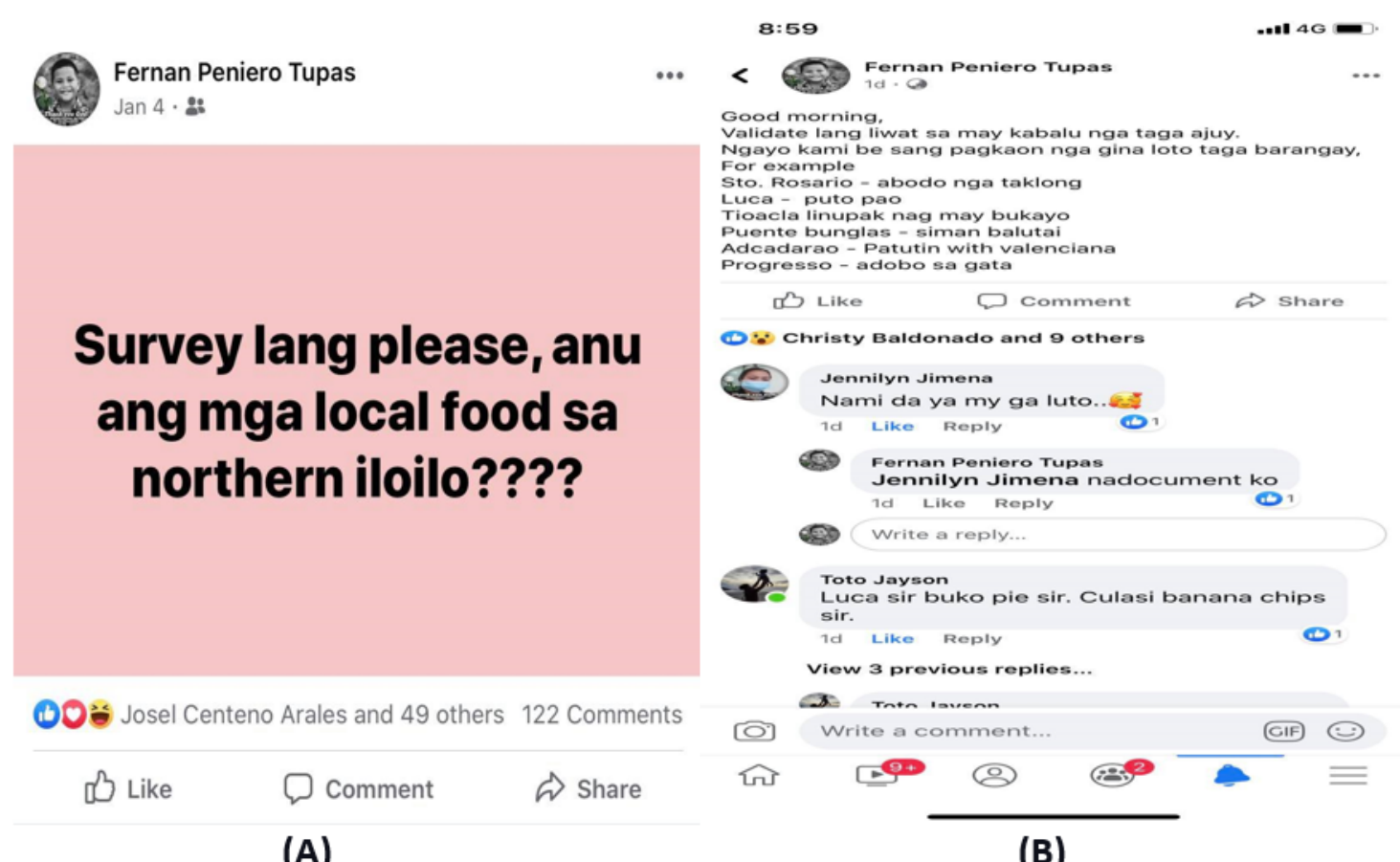

(A)

(B)

Fig 2. The questions wereposted on FB.

The researchers visited the 34 barangays and surveyed them before the implementation of the study. Thus, barangays with no known or have a similar product were eliminated as study areas. This visitation happened last November to December 2019. 
Table 1 shows the informants in this study.

Table 1. Informants of thestudy

\begin{tabular}{llll}
\hline Participants & Age & Expertise & Total Number \\
\hline LGU & $40-60$ & Knowledge about Ajuy's culture and history & 2 \\
Barangay Officials & $25-63$ & Knowledge about local culture and history & 7 \\
Food Experts & $30-76$ & Cook different delicacies commonly prepared in Ajuy & 5 \\
Teachers & $35-60$ & Used in teaching & 10 \\
Housewife & $27-55$ & Cook local dishes for daily consumption & 15 \\
Cook & $47-69$ & Prepared as one of the dishes on any occasion & 5 \\
A local Food stall owner & $50-70$ & Selling local food & 2 \\
Students & $16-22$ & Hotel and Restaurant Management, and TechVoc (Major in & 25 \\
& & culinary) & 71 \\
\hline Total & &
\end{tabular}

The researchers visited the 34 barangays and surveyed them before the implementation of the study. Thus, barangays with no known or have a similar product eliminated as study areas. This visitation happened last November to December 2019.

The researchers purposively selected the informants because they already have the knowledge and to create a good rapport during the collection of data. Furthermore, the researchers made guide questions and an open-ended ready-made-questionnaire during the interview and focus group discussion. They also produce a guide for the observation. Five experts validated the instruments in science as well as in culinary.

The dishes and delicacies identified are commonly found during special occasions, market day, in the food stall, and sold during the afternoon served as snacks to the residents.

Furthermore, tape-recorded was also used during the interview to guarantee that all responses were captured in detail. In the observation, the cellphone camera used to take pictures to validate all the information gathered. After four months, all data collected were evaluated, assessed, and analyzed. The responses from the interviews and FGD, and the observation were transcribed, coded, theme, and triangulated.

\subsection{Ethical Consideration}

The researchers followed proper protocol in doing research. They distributed a permit for the identified informants and set a day to explain the study. They hide the real identity of the informants by using codenames.

\section{Results and Discussion}

\subsection{Ajuy's Unique Dishes}

Table 2 shows the local dishes in the Municipality of Ajuy.

Table 2. The local dishes identify famous in selected Barangays in Ajuy.

\begin{tabular}{lll}
\hline \multirow{2}{*}{ Barangay } & & Dishes \\
\cline { 2 - 3 } & Hiligaynon Name & English Name \\
\hline Adcadarao & $\bullet$ Patotin with Valenciana & $\bullet$ Duck stew filled Valenciana \\
\hline Badiangan & $\bullet$ Binakol nga bisaya nga manok sa kawayan & $\bullet$ Native Chicken Soup cooked in Bamboo \\
\hline Pili & $\bullet$ Ginisa nga Green Shell & $\bullet$ Stir-fried green shell \\
& $\bullet$ Torta (Puso sang saging) & $\bullet$ Banana blossom burger \\
\hline Progresso & $\bullet$ Adodo sa Gata & $\bullet$ Meat (like chicken or pork cooked in soy sauce and \\
& $\bullet$ Linutik sa Labog and banag & vinegar) with coconut milk \\
& $\bullet$ Bdobo nga Taklong & $\bullet$ Snail cooked in soy sauce and vinegar \\
\hline Sto. Rosario & $\bullet$ Tinum-an nga kan-on sa tuba & $\bullet$ Cooked in "Tuba" - local vinegar from coconut tree \\
\hline Tipacla & $\bullet$ Linabogan nga bisaya nga manok & $\bullet$ Chicken soup is spiced with ginger, lemongrass, garlic, \\
& & onion, and tomatoes boiled with coconut water. \\
\hline
\end{tabular}


Out of thirty-four barangays in Ajuy, six have produced unique dishes; however, in Adcadarao, "Patotin" or whole stewed duck with a twist, stuffed sticky rice, boiled egg, hotdogs, green peas, and "chorizo bilbao." Furthermore, in Progresso, adobo is traditionally cooked in soy sauce and vinegar, but with a twist. Coconut milk was used as an additional ingredient to make it more tasty and different from "abodos" in other places in the entire archipelago. But "Patotin filled with Valencia" was the stand-out.

\subsection{Ajuy's Delicacies}

Table 3 shows the local delicacies in the Municipality of Ajuy

Table 3. The local delicacies in selected Barangays in Ajuy.

\begin{tabular}{|c|c|c|}
\hline \multirow{2}{*}{ Barangay } & \multicolumn{2}{|c|}{ Delicacies } \\
\hline & Hiligaynon Name & English Name \\
\hline Culasi & - Banana chips & - Banana Chips \\
\hline Luca & $\begin{array}{l}\text { - Puto Pao } \\
\text { - Buko Pie }\end{array}$ & $\begin{array}{l}\text { - A steamed cake filled with pork } \\
\text { - Buko Pie filled with fresh young coconut }\end{array}$ \\
\hline Mangorocoro & - Empanada nga Mongo & - Filled with sweetened mongo \\
\hline Pantalan Nabaye & - Ginamos & - Salted or fermented fish (anchovy) \\
\hline Pili & - Ginamos nga hipon & - Shrimp paste \\
\hline Pinay Espinosa & - Butchi nga may bukayo & $\begin{array}{l}\text { - Pastry made from glutinous rice filled sweetened } \\
\text { coconut }\end{array}$ \\
\hline Poblacion & $\begin{array}{l}\text { - Kalamayhati Suman } \\
\text { - Bitso-bitso } \\
\text { - Sulpot } \\
\text { - Cassava Cake } \\
\text { - Buko Pie }\end{array}$ & $\begin{array}{l}\text { - Glutinous rice cake cooked in coconut milk and } \\
\text { muscovado sugar } \\
\text { - Rice dough coated with coconut cream and } \\
\text { muscovado sugar syrup } \\
\text { - Steam Rice wrapped with banana leaves } \\
\text { - Cassava Cake } \\
\text { - Buko Pie }\end{array}$ \\
\hline Progresso & $\begin{array}{l}\text { - Cassava suman } \\
\text { - Barikutsa }\end{array}$ & $\begin{array}{l}\text { - Cassava cake } \\
\text { - Sugar and coconut milk candy }\end{array}$ \\
\hline Puente Bunglas & - Soman balutai & - Steam rice with coconut and sugar syrup \\
\hline San Antonio & - Atchara with Sampaliya & - Pickle papaya with \\
\hline Tipacla & - Linupak na Saging nga may bukayo & - Smash banana filled with coconut candy \\
\hline
\end{tabular}

Eleven Barangays have local delicacies. All these delicacies are not initially from Ajuy; however, the availability and abundance of resources from fishery and agricultural products inspire residents to adopt some recipes from other locality. But with some ingenuity, some residents mixed some available products to become unique and different from other towns. For instance, "Linupak nga Saging" or "Linuyag," a mashed banana in a big wooden mortar and brushed with margarine, but in Tipacla "bukayo" or sweetened coconut strips as fillings to make more delicious.

In the 90s, Pili produced small fermented shrimps or "ginamos na hipon" and green shell cooked with spices and ginger; the abundance of the organisms in the area encouraged the residents to do business. But today, shrimps and green were already vanishing. But "barikutsa" stood out from the survey. This coconut candy is processed in unique techniques and is not common.

But in the early 2000s, one prominent family introduced buko pie and cassava custard; from then on, it becomes Ajuy's native delicacies. Many residents, both from the municipality and neighboring places, visit Ajuy to grab these two delicious mouth-watering recipes. Even families and friends abroad requesting love ones to bring them boxes of buko pie and cassava custard as pasalubong.

After Typhoon Haiyan, Ajuy is one of the municipalities in the Western Visayan, a hard hit. Many organizations, both public and private, extend help to the residents of the municipality. One of those is the Adventist Development and Relief Agency (ADRA) Philippines. Specifically, ADRA helps during disasters and improve the lives of affected families through livelihood programs ${ }^{(41)}$. Two of the barangays in the municipality were recipients of this organization. They trained Barangay Culasi for Banana Chips and Barangay Luca for Buko Pie; selected families will allow them to sell this product to have income. Barikutsa has excellent potential as products of Ajuy. 


\subsection{Unveiling the Mystery of Local Dishes and Delicacies}

Figure 3 shows the prognostic map on local dishes and delicacies in the Municipality of Ajuy.

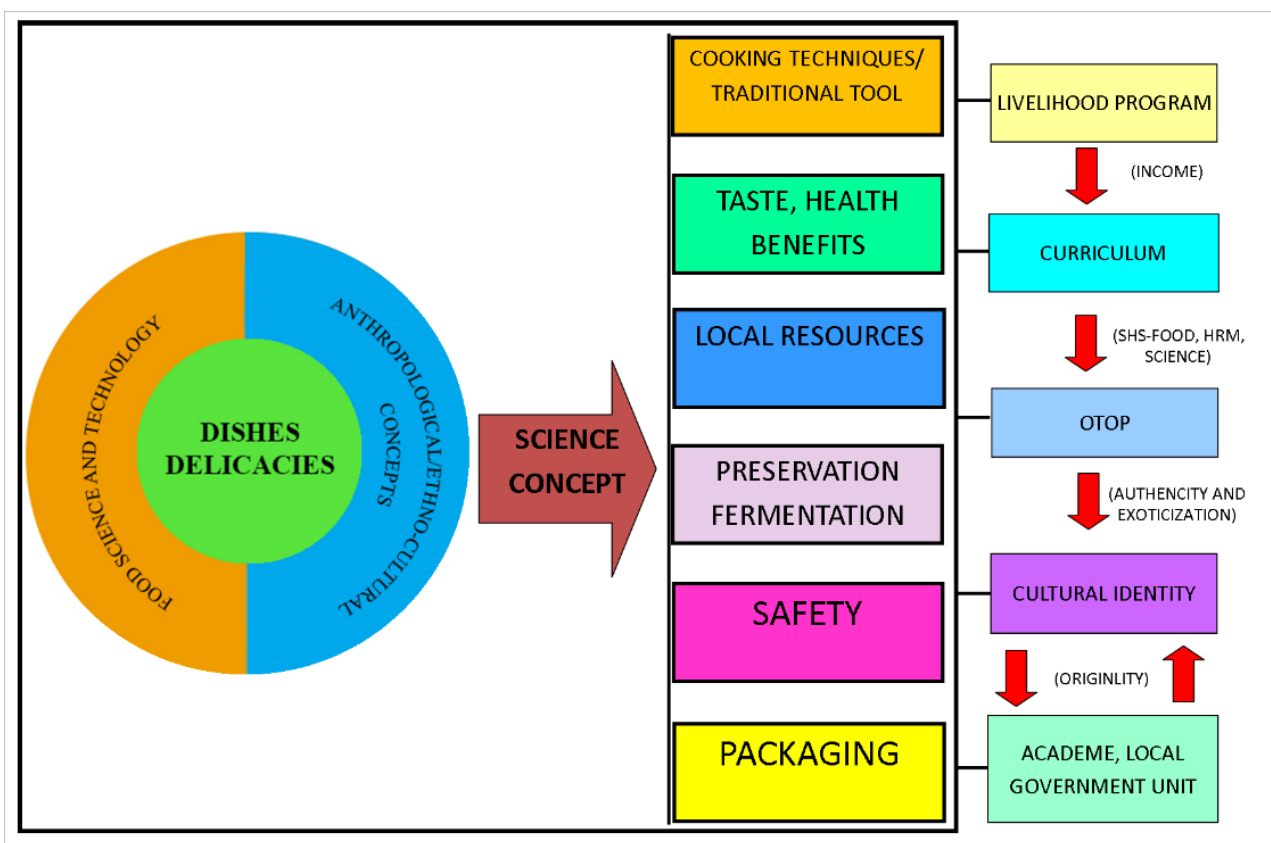

Fig 3. Prognostic Map.

Anthropological and ethnocultural concepts and food science and technology are always linked to local dishes. Technically, Filipino dishes are a combination of recipes from different countries like China, Spain, and the US. However, the abundance of resources such as seafood, fish sauce, and cream-style shrimp paste are common condiments in Filipino households ${ }^{(15)}$, and producing rice, vegetables, meats are part of the lifestyle of the community and become their culture ${ }^{(19)}$. According to Aileen Suzara, chef, food educator, and advocate, aims to endorse sustainable and healthy Pinoy food practices. She further stressed Filipino food culture tied to the land, sea, and seasons ${ }^{(42)}$. With more than 7,107 islands in the archipelago, national dishes like "adobo" are always served with a twist ${ }^{(15)}$. Just like beer, local cuisine around the world is always associated with festivals and regions ${ }^{(17)}$. For instance, in the Philippines, cooking "pancit" (a Filipino noodles) or Filipino spaghetti, people think there is a birthday celebration or "lechon" or roasted pig, the community is celebrating a fiesta ${ }^{(19)}$. Food bringing Filipino together. Also, food science and technology is an essential aspect of local cuisine due to food choices as well as preparations. Dietary intake and health have a significant impact on food preparations ${ }^{(22)}$. The majority of people prepared food for potential benefits. Just like in the Philippines, the natural way of cooking without preservatives found in traditional dishes and delicacies.

Thus, there were ten science concepts identified by the informants in the local dishes and delicacies in the Municipality of Ajuy. These were cooking techniques, traditional tools, taste, health benefits, local resources, preservation, fermentation, safety, and packaging. Cooking is science but associated with chemistry ${ }^{(43)}$. The process and application of how these delicacies are prepared and cooked are already science. The art of cooking is as old as science.

Furthermore, to improve the cooking method is to understand the scientific bases. Also, creating new approaches to enhance the quality of the dishes resulted in innovations ${ }^{(44)}$. The science behind these local dishes is mastering traditional cooking. The tools used were all productive with innovative minds-resources like stones or tree twigs used as traditional cooking tools.

Additionally, ingredients used in some of the cooking, such as oil, soy sauce, vinegar is the product of a laboratory. But the major elements in all these dishes are locally available in the areas. The recipe stating the measurement and instruction combining all the ingredients and energy to produce delicious dishes is also a science ${ }^{(43)}$.

Another science concepts found in all the delicacies are taste, but this is more linked to custom, geography, principles, and human associations. Sensory perception is also essential; the critical concept is flavor incorporating all physical, chemical, and neurophysiological aspects |45|. Aside from environmental factors, genetic makeup impacts food choices and taste. These taste characteristics like sweet, sour, salty, and bitter, are sensed due to chemicals that bind with the receptor on the human tongue. 
Furthermore, these essential receptors of tastes such as bitter, sweet, umami, sour, and salty are all found in the local delicacies in Balasan and Estancia. Thus, science is already embedded because bitter, sweet, and umami appear to belong to the same superfamily of G-protein-coupled receptors. The receptor for salty is an ion channel. And for the sour, this may involve some proton sensing ${ }^{(45)}$. Filipino cuisines are a mixture of salty, sweet, and spicy.

Furthermore, Filipino foods are healthy. The traditional methods for Filipino cuisines are boiling, steaming, grilling, and naturally fermenting or preserving. Freshly served like kinilaw is commonly staple food in the islands. ${ }^{(42)}$. But all the local foods in Ajuy cooked healthy, with no preservatives or processed ingredients added in the gastronomies.

Ajuy, like the granary of agriculture products, many dishes can be introduced and invented by the residents. The geographical location of Ajuy also one factor that it has both farm and fishing products

There are two essential methods used in delicacies drying and fermentation. Drying is the oldest method of food preservation. Also, fermentation is used to prevent spoilage ${ }^{(46)}$. In the process of drying the fish, scientific concepts were already embedded a century ago. This process is called fermentation. The salt is used for conservation due to microbial enzymes ${ }^{(47)}$. The discovery of improved methods of drying on ribbonfish could result to free from coliform organisms and stayed longer compared to traditional methods. Thus, the LGU must venture into ascertaining new techniques to develop the dried fish industry ${ }^{(48)}$. Also, the use of vinegar as a preservative in cooking local dishes unveiled scientific concepts. Vinegar act as preservatives. Also, it adds an exceptional flavor to the finished products due to lactic acid fermentation. The life span of the dishes cooked in vinegar is longer.

Another science concepts found in these local products are safety practices. Some documents showed producing these delicacies in open spaces-also, no protective gears were used during the production of these local delicacies. There were no regulations among the two municipalities about this issues. One of the common problems of the producers and vendors of native delicacies in Bayombong, Pangasinan, is food safety and practices. The LGU on the health and licensing office must create specific regulations to stop this problem. Thus, training about food safety and techniques is required ${ }^{(49)}$. The food safety control and regulatory systems in the Philippines face different trials. The national Food Safety Network comprises agriculture and fisheries, the food industry, the foodservice sector, and the consumers. But due to various regulatory agencies is therefore highly fragmented with plenty of overlap and gaps; thus, a call to standardize to have a single authority to regulate the delivery of safer food ${ }^{(50)}$.

Moreover, some of the delicacies in Ajuy were packed with banana leaves. Nowadays, there are different packaging systems -active packaging and intelligent packaging or smart packaging. For products like food, active packaging is an innovative approach used for safety and retain quality. Nanotechnology packaging is one controversial innovation because many were hesitant due to some effects ${ }^{(25)}$. But since this technology required a large amount, traditional methods must be appropriately enhanced. Thus, there was no environmental impact on the packaging used in all Ajuy's cookeries.

The unveiling of the best local dishes and delicacies in Ajuy can provide livelihood programs to the locals. Livelihood is to offer ways and means of living. The poor and vulnerable individuals live with the help of an organization that focused on people-centered, receptive, and hands-on, multi-levels, conducted in partnership with public and private sectors, active and workable ${ }^{(51)}$. The program of the Department of Social Hence, LGU, NIPSC, and private organizations like ADRA can work together to help residents to uplift lives. The Department of Social Works and Development (DSWD) offers the Sustainable Livelihood Programs (SLP) for extra income, business extension, and continuous service of employment but faces various issues and challenges ${ }^{(52)}$. Thus, LGU, like Ajuy, learned from the experiences and created a development plan for effective implementation.

Also, these can provide a new avenue for curriculum enhancement in basic education programs, culinary arts in Hotel and Restaurant Management (HRM) as well as science. There are secondary schools in the district offering culinary arts in Senior High School. Also, HRM in NIPSC is teaching students to prepare different types of cuisine. Accordingly, teaching students the different kinds of local dishes and delicacies commonly found in the municipality helps them understand the unique culture of Ajuy and develop an interest to innovate using local products.

The OTOP's MMSE showcases the local talents, using indigenous materials and increasing employment among the residents ${ }^{(53)}$. Hence, the Municipality of Ajuy, with the help of several stakeholders coming from the private and public sectors to concentrate on improving local delicacies because this can support employment. There were also fascinating and picturesque destinations in both municipalities, and this delicacy can also boost tourism. For the past years, in OTOP's of the province or by DTI, Ajuy always exhibited only dried fish and native furniture. But developing some selected local dishes and delicacies enhance with local resources can provide new products during OTOP. These products offer livelihood programs for the residents. The finding of the current study helps the Municipality of Ajuy document the history of local dishes and delicacies. Thus, the Hospitality Management Department of NIPSC Ajuy Campus can help in improving the quality and standard of these local recipes by conduct more studies. And later, train the residents on how to make these improve dishes and delicacies. This program 
will serve as an extension of the college.

\section{Conclusion}

Food is life for every Filipino. From simple occasions to grand gatherings, food is always overflowing. Filipino food is a mixture of western and local; the savory taste and ethnicity make our dishes and delicacies unique. Out of 34 barangays in the Municipality of Ajuy, 6 have local dishes and 11 for local delicacies. However, the majority of these foods were not locally from Ajuy. These dishes and delicacies were adapted from neighboring places and islands because of local products in Ajuy, known as fisheries and agricultural granary in the north. All the identify food, "barikutsa" for delicacy, and "Patotin filled with Valenciana" for dish stood out the most. However, local Filipino foods are always interconnected to anthropological and ethnocultural perspective. The Philippine cuisines are recipes adopted from China, Spain, the US, and other countries. The availability of resources is part of the lifestyles and becomes their culture. Also, food practices, preparations, techniques, and tools are intertwined with food science and technology. These concepts are crucial to unveil science concepts in the unique cuisines in the Municipality of Ajuy. According to the informants, nine science concepts are embedded in the collected dishes and delicacies. These were cooking techniques, traditional tools, taste, health benefits, local resources, preservation, fermentation, safety, and packaging. The local foods were processed naturally with no preservatives and packed in banana leaves or other locally found resources. Thus, foods were healthy and didn't contribute to environmental problems. The discovery can help Ajuynons through livelihood programs, enhance curriculum, participation in OTOP, and cultural identity of the town and the people. However, various stakeholders play a significant role, like Northern Iloilo Polytechnic State College (NIPSC), Ajuy Campus, by integrating these local foods into the subjects of their culinary art. Also, tapped secondary education majoring in food in Technology and Livelihood Education subject to train learners on how to cook "Barikutsa" and "Patotin filled with Valenciana." With the help of the local government unit through financial support and encouragement to make this proposal in reality. Furthermore, the Municipality of Ajuy should create a committee to discover local cuisines and delicacies, and tapped food experts to improve Ajuy's best and uniques gastronomies to boost tourism and the way of lives of the locals because more jobs will be available.

\section{Acknowledgment}

The authors would like to extend heartfelt gratitude to all Ajuynons who participated in this endeavor. This research would not have completed without their time and effort.

\section{References}

1) Masigan AJ. Trends in the food industry. 2019. Available from: https://www.bworldonline.com/trends-in-the-food-industry/.

2) Platon CC, Pambid RC, Lomboy E. Food safety practices among native delicacy producers and vendors in the public market of Bayombong in. Asia Pacific Journal of Education, Arts, and Science. 2017;4(2):95-102.

3) Chaneac S. 10 Famous foods you must try in the Philippines. 2019. Available from: fromttps://nomadicboys.com/famous-foods-philippines.

4) Fernandez D. Philippine Food Culture and History. 2019. Available from: https://asian-recipe.com/philippine-food-culture-and-history-2467.

5) Raji MNA, Karim SA, Ishak FAC, Arshad MM. Past and present practices of the Malay food heritage and culture in Malaysia. Journal of Ethnic Foods. 2017;4(4):221-231. Available from: https://dx.doi.org/10.1016/j.jef.2017.11.001.

6) Momblam G. DOT Promotes Panay's farm culinary tourism. 2019. Available from: https://www.pna.gov.ph/articles/1088186.

7) Nagallo AK. A research study on the processes and methods used in making native sweet delicacies in Brgy. Trapiche, Oton, Iloilo. 2016. Available from: fromhttps://huminamingmahal2016.wordpress.com/2016/12/07/a-research-study-on-the-processes-and-methods-used-inmaking-native-sweet-delicacies-in-brgy-trapiche-oton-iloilo/.

8) Parilla ES. Economic Promotion through One-Town One Product. International Journal of Academic Research in Business and Social Sciences. 2013;3(7). Available from: https://dx.doi.org/10.6007/ijarbss/v3-i7/75.

9) Segador M. The pride of Iloilo: Semana sang Iloilo. 2012. Available from: http://iloiloilove.com/semana-sang-iloilo-2012-part-1/.

10) Tupas FP, Matsuura T. Moving forward in STEM education, challenges, and innovations in Senior High School in the Philippines: the case of Northern Iloilo Polytechnic State College. Jurnal Pendedika IPA Indonesian. 2019;8(3):406-416. Available from: https://doi.org/10.15294/jpii.v8i3.19707.

11) Cinco MCL, Makalintal LGM, Montemor DRC, Sawali JA. Famous selected municipalities in the Province of Laguna: A Tourist Attraction for Culinary Tourism. 2014. Available from: http://research.lpubatangas.edu.ph/wp-content/uploads/2014/08/JTHR-Famous-Delicacies.pdf.

12) Galvez JCP, Lopez-Guzman T, Buiza FC, Medina-Viruel M. Gastronomy as Element of Attractions in a Tourist Destination: The Case of Lima. Peru Journal of Ethnic Food. 2017;4(4):254-261. Available from: https://doi.org/101.016/j.jerf.2017.11.002.

13) Liba RT, Reyes ARC, Alea AJA, Barros HJS, Rosas PARD, Torre ARSD, et al. Native Rice Delicacies of Naic, Cavite: An Exploratory Study of Gastronomical Past, Present and Future. Journal of Tourism Research \& Hospitality. 2017;06(03). Available from: https://dx.doi.org/10.4172/2324-8807.1000170.

14) Hamlett C, Group L. Leaf Group. Food culture in the Philippines. 2020. Available from: https://traveltips.usatoday.com/food-culture-philippines-17408. html.

15) Sim D. Filipino cooking and culture. 2019. Available from: https://www.thespruceeats.com/filipino-cooking-and-culture- 3030285.

16) Edwardes M. The origins of self: an anthropological perspective. UCL Press. 2019. Available from: https://doi.org/10.2307/j.ctv13xprvd.

17) Turek J. Beer, pottery, society, and early European identity. Journal of World Archaeological Congress. 2017;p. 396-423. Available from: https: //doi.org/10.1007/s11759-020-09406-7. 
18) Miller MJ, Whelton HL, Swift JA, Maline S, Hammann S, Cramp LJE, et al. Interpreting ancient food practices: stable isotope and molecular analyses of visible and absorbed residues from a year-long cooking experiment. Scientific Reports. 2020;10(1):1-16. Available from: https://dx.doi.org/10.1038/ s41598-020-70109-8.

19) Mercado JMT, Zerrudo EB. Pamanang Kulinarya: developing safeguarding plan for culinary heritage using the statement of significance - the case of "lomi. Journal of Archaeology and Fine Arts in Southeast Asia. 2018;2:1-33.

20) Alejandria MCP, Vergara TIMD, Colmenar KPM. The authentic balut: history, culture, and economy of a Philippine food icon. Journal of Ethnic Foods. 2019;6(1):16-17. Available from: https://dx.doi.org/10.1186/s42779-019-0020-8.

21) Zapico FL, Aguilar CH, Abistano A, Turner JC, Reyes LJ. Biocultural Diversity of Sarangani Province, Philippines: An Ethno-Ecological Analysis. Rice Science. 2015;22(3):138-146. Available from: https://dx.doi.org/10.1016/j.rsci.2015.05.018.

22) Mills S, White M, Wrieden W, Brown H, Stead M, Adams J. Home food preparation practices, experiences and perceptions: A qualitative interview study with photo-elicitation. PLOS ONE. 2017;12(8). Available from: https://dx.doi.org/10.1371/journal.pone.0182842.

23) Martínez-Monzó J, García-Segovia P, Albors-Garrigos J. Trends and Innovations in Bread, Bakery, and Pastry. Journal of Culinary Science \& Technology. 2013;11(1):56-65. Available from: https://dx.doi.org/10.1080/15428052.2012.728980.

24) Martin N. How technology is transforming the food industry. 2019. Available from: https://www.forbes.com/sites/nicolemartin1/2019/04/29/howtechnology-is-transforming-the-food-industry/\#2250405d20a3.

25) Guiné RPF, Ramalhosa ECD, Valente LP. New Foods, New Consumers: Innovation in Food Product Development. Current Nutrition \& Food Science. 2016;12:175-189. Available from: https://dx.doi.org/10.2174/1573401312666160608120727.

26) Heisey N, Kucan L. Introducing Science Concepts to Primary Students Through Read-Alouds: Interactions and Multiple Texts Make the Difference. The Reading Teacher. 2010;63:666-676. Available from: https://dx.doi.org/10.1598/rt.63.8.5.

27) Ingmire A. Learning by doing help students perform better in science. 2015. Available from: https://news.uchicago.edu/story/learning-doing-helpsstudents-perform-better-science.

28) The University of California Museum of Paleontology, Berkeley, and Regents of the University of California. What is Science?. . Available from: www.understandingscience.org.

29) Ideboen A. Science concept for kids. 2019. Available from: https://sciencing.com/science-concepts-for-kids-12745981.html.

30) Lestari N, Fajar F. Physics Education based Ethnoscience: Literature Review. In: and others, editor. International Conference on Mathematics, Science, and Education. 2016.

31) Fasasi RA. Effects of ethnoscience instruction, school location, and parental educational status on learners' attitude towards science. International Journal of Science Education. 2017;39(5):548-564. Available from: https://dx.doi.org/10.1080/09500693.2017.1296599.

32) Gunawan YY, Sarwanto, Nurosyid F. The analysis of students' critical thinkings skills through ethnoscience instruction integrated on the topic magnetic field. In: and others, editor. AIP Conference Proceeding. 2019. Available from: https://doi.org/10/10631/1.5139765.

33) Abonyi OS, Achimugu L, Nyuko, Adike MI. Innovations in Science and Technology Education: A case of Ethnoscienve Based Classroom. International Journal of Scientific \& Engineering Research. 2014;5(1):52-56.

34) Swiderska K, Song Y, Li J, Reid H, Mutta D. Adapting agriculture with traditional knowledge. 2011. Available from: https://pubs.iled.org/17111IIED.

35) Sudarmin, Febu R, Nuswowati M, Sumarni W. Development of Ethnoscience Approach in The Module Theme Substance Additives to Improve the Cognitive Learning Outcome and Student's entrepreneurship. Journal of Physics: Conference Series. 2017;824. Available from: https://dx.doi.org/10.1088/ $1742-6596 / 824 / 1 / 012024$.

36) Dirks R, Hunter G. The Anthropology of Food. 2013. Available from: https://www.academia.edu/1901765/The_Anthropology_of_Food?auto=download.

37) Wintz SW, Bois CMD. CM. The Anthropology of Food and Eating. Annu Rev Anthopol. 2002;31:99-119.

38) Crossman A. Understanding functionalist theory. 2020. Available from: https://www.thoughtco.com/functionalist-perspectove- 3026625.

39) Digital Tourism Digital. Ajuy. 2018. Available from: https://myguide.ph/ajuy/.

40) Province of Iloilo. Ajuy. 2020. Available from: http://iloilo.gov.ph/municipality/ajuy.

41) ADRA. About ADRA. 2019. Available from: https://adra.ph/about-adra/.

42) Liwanag-Bledsoe M. Changing our perceptions of unhealthy Filipino food. 2019. Available from: https://www.asianjournal.com/life-style/eat-drink/ changing-our-perception- of-unhealthy-filipino-food/.

43) Henry A. How to improve your home cooking with the power of science. 2013. Available from: https://lifehacker.com/how-to-improve-your-homecooking-with-the-power- of-scie-511405909.

44) Cassi D. Science and cooking: the era of molecular cuisine. EMBO reports. 2011;12(3):191-196. Available from: https://dx.doi.org/10.1038/embor.2011.18.

45) Mouritsen OG. The science of taste. Flavour. 2015;4(1). Available from: https://dx.doi.org/10.1186/s13411-014-0028-3.

46) Gabbay S. The Science of food preservation. 2015. Available from: fromhttps://www.alive.com/health/the-science-of-food-preservation/.

47) Staton WR, Owens JD. Fermented foods (Fermentation of the Far East). In: and others, editor. Encyclopedia of Food Science and Nutrition . 2003.

48) Relekar SS, Joshi, Sa, Gore SB, Kulkarni AK. Effect of improved drying Method on the biochemical and microbiological quality of dried small head ribbon fish (Lepturacanthus savala). International Journal of Fisheries and Aquatic Studies. 2014;1(5):60-66.

49) Platon CC, Pambid, Rc, Lomboy E. Food safety practices among native delicacy producers and vendors in the public market of Bayombong in. Asia Pacific Journal of Education, Arts, and Science. 2017;4(2):95-102.

50) Collado LS, Corke H, Dizon EI. Food safety in the Philippines: problems and solutions. Quality Assurance and Safety of Crops \& Foods. 2015;7(1):45-56. Available from: https://dx.doi.org/10.3920/qas2014.x008.

51) Serrat O. The sustainable livelihood approach. Knowledge Solution. 2008;15:1-5.

52) Ballesteros M, Orbeta A, Corpus JP, Ancheta J. Assessment of livelihood success and implementation, issues on the sustainable livelihood program (SLP) of the DSWD. Quezon City, Philippines. Philippine Institute for Development Studies. 2018.

53) Parilla ES. Economic Promotion through One-Town One Product. International Journal of Academic Research in Business and Social Sciences. 2013;3(7). Available from: https://dx.doi.org/10.6007/ijarbss/v3-i7/75. 